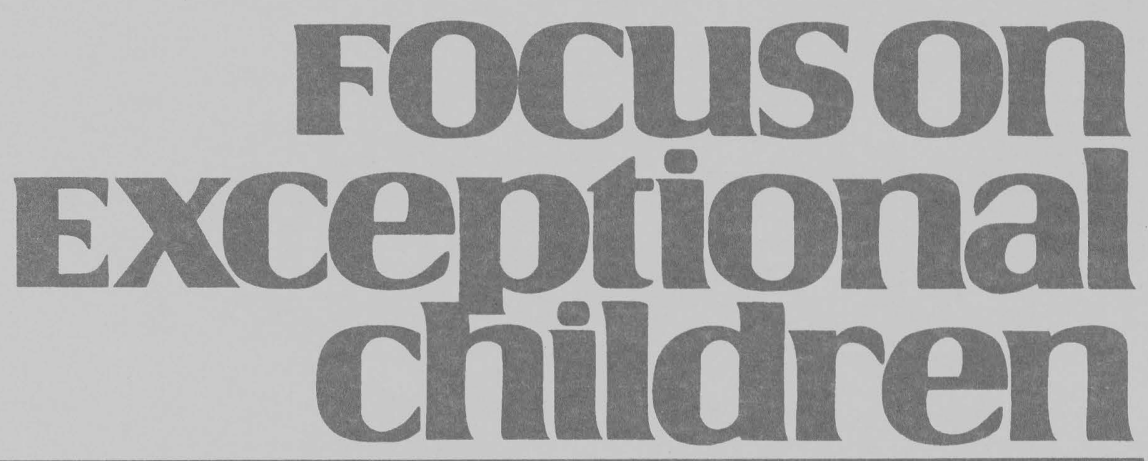

\title{
A Legal Roadmap of SBR, PRR, and Related Terms under the IDEA
}

\author{
Perry A. Zirkel
}

The literature of special education generally and special education law specifically tends to use "scientifically based research" (SBR), along with its shorthand "scientifically based" variation, and related terms such as "evidence-based," "research-based," and "peerreviewed research" (PRR) rather loosely and even interchangeably. This lack of differentiation causes problems in terms of potential litigation in this highly legalized, perhaps "over-legalized" (Zirkel, 2005), field. For school districts, or local education agencies (LEAs), the problem is compounded by confusion between what is legally required and what is professionally recommended.

For example, Turnbull (2005, p. 321) characterized the 2004 amendments of IDEA as reiterating the NCLB "requirement" for "scientifically based instruction (SBR; sometimes called evidence-based instruction)." Similarly, other respected special education law experts (e.g., Crockett \& Yell, 2008) have used SBR and PRR without clear differentiation. Even the U.S. Department of Education (USDE) publications advocate "evidence-based" interventions in relation to implementation of NCLB, which is the basis for the IDEA definition of SBR (e.g. IES, 2003), without differentiation or clarification.

This article maps out the overall differences in this increasingly important terminology under the 2004 amendments and 2006 regulations of the Individuals With Disabilities Education Act (IDEA). Although not demarcating precisely bright lines, the legislation, regulations, and related USDE policy interpretations contribute to a significant differentiation among these various terms.

As Figure 1.1 illustrates, the legal scope of these various terms may be visually organized into approximately situated circles. The explanation herein starts with the central terms "SBR" and "PRR" and proceeds to the outermost term, "evidence-based."

\section{SBR v. PRR}

As explained in more detail elsewhere (Zirkel \& Rose, 2008), the IDEA regulations (2007, $\S 300.25$ ) define SBR by incorporating the definition in NCLB, which in turn

Perry A. Zirkel is a professor of education and law at Lehigh University. 


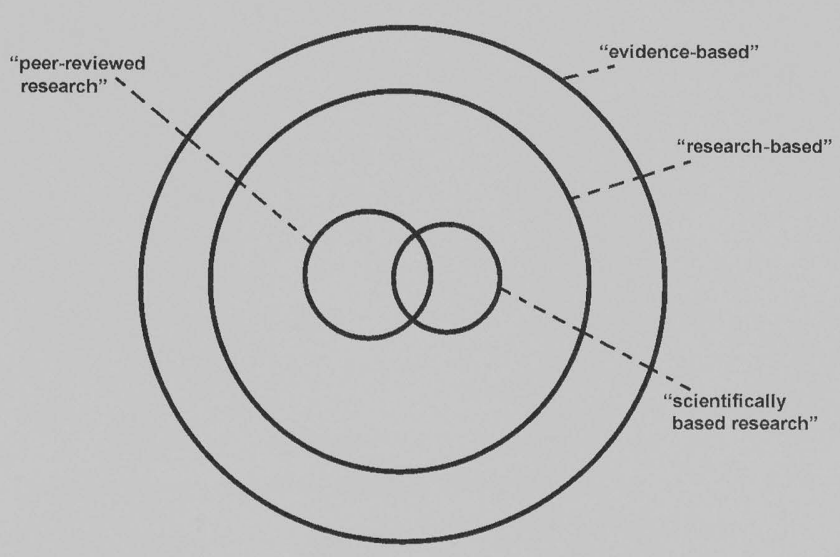

FIGURE 1.1

Schematic Differentiation of Terminology

\section{Focuson
Exceptional children}

ISSN 0015-511X FOCUS ON EXCEPTIONAL CHILDREN (USPS 203-360) is published monthly except June, July, and August as a service to teachers, special educators, curriculum specialists, administrators, and those concerned with the special education of exceptional children. This publication is annotated and indexed by the ERIC Clearinghouse on Handicapped and Gifted Children for publication in the monthly Current Index to Journals in Education (CIJE) and the quarterly index, Exceptional Children Education Resources (ECER). The full text of Focus on Exceptional Children is also available in the electronic versions of the Education Index. It is also available in microfilm from Serials Acquisitions, National Archive Publishing Company, P.O. Box 998, Ann Arbor, MI 48106-0998. Subscription rates: individual, $\$ 42$ per year; institutions, \$56 per year. Copyright (C) 2008, Love Publishing Company. All rights reserved. Reproduction in whole or part without written permission is prohibited. Printed in the United States of America. Periodical postage is paid at Denver, Colorado. POSTMASTER: Send address changes to:

Love Publishing Company

Executive and Editorial Office P.O. Box 22353

Denver, Colorado 80222

Telephone (303) 221-7333

\section{EDITORIAL BOARD}

Lisa Dieker

University of Central Florida
Paula Maccini University of Maryland

Marleen Pugach

University of Wisconsin-Milwaukee

Carrie E. Watterson Editor
Stanley F. Love

Publisher consists of two parts—an overall descriptor "and," followed by "includes," a set of specific characteristics, or criteria. Specifically, the definition is as follows:

(A) ... research that involves the application of rigorous, systematic, and objective procedures to obtain reliable and valid knowledge relevant to education activities and programs, and

(B) Includes research that:

(i) employs systematic, empirical methods that draw on observation or experiment;

(ii) involves rigorous data analyses that are adequate to test the stated hypotheses and justify the general conclusions drawn;

(iii) relies on measurements or observational methods that provide reliable and valid data across evaluators and observers, across multiple measurements and observations, and across studies by the same or different investigators;

(iv) is evaluated using experimental or quasi-experimental designs in which individuals, entities, programs, or activities are assigned to different conditions and with appropriate controls to evaluate the effects of the condition of interest, with a preference for random-assignment experiments, or other designs to the extent that those designs contain within-condition or across-condition controls;

(v) ensures that experimental studies are presented in sufficient detail and clarity to allow for replication or, at a minimum, offer the opportunity to build systematically on their findings; and

(vi) has been accepted by a peer-reviewed journal or approved by a panel of independent experts through a comparably rigorous, objective, and scientific review. (NCLB, § 7801(37))

The major features of this definition are that (1) the scope is limited largely to experimental and quasi-experimental research, although only preferring rather than requiring the "gold standard" of experimental research using random assignment; and (2) the sixth criterion encompasses, and effectively defines, PRR.

PRR, however, effectively overlaps with, rather than being a subset of, SBR. The reason is that many research studies that undergo this process do not meet the other criteria of SBR. In addition, PRR is often associated with socalled "blind review," whereas the language of sixth criterion does not specify this feature. Although the education literature (e.g., Graue, 2006), like the medical literature from which SBR and PRR were imported (e.g., "Peer Review"), have identified various needs for improvement in the peer-review process, the literature in both special education literature and general education have largely neglected not only this overlapping SBR-PRR interrelationship but other legal guidance as well, as to their differentiation from the related terms of "research-based" and "evidence-based." 


\section{Other Legal Differentiation}

In the only systematic analysis of the IDEA legislation, regulations, and the related sources of legal guidancespecifically, the USDE interpretations in the Commentary (2006) for the IDEA regulations and more recent policy pronouncements of its Office of Special Education Programs (OSEP) - Zirkel and Rose (2008) concluded that most of the references to SBR and its variants apply to state education agencies (SEAs) rather than local education agencies (LEAs), and that most of the references are permissive rather than mandatory.

In contrast to what is commonly conceived or advocated in the special education literature, the references in IDEA specific to LEAs are limited to four largely permissive, rather than unconditionally mandatory, situations. First, IDEA 2004 and its 2006 regulations permit-rather than require-interventions that are "scientific, research based" under what is referred to much more popularly as "response to intervention" (RtI) in the revised provisions for determining eligibility for specific learning disability (SLD). Second, the regulations add as another option beyond severe discrepancy-depending initially on the choice of each state"other alternative research-based procedures" for SLD identification. Third, the legislation refers to "scientifically based" instruction in the new, similarly permissive provision of "early intervening services" in general education. Finally, IDEA has a conditional-that is, "to the extent practicable"-requirement for PRR to the IEP's specification of specially designed instruction and related services.

The related sources of legal guidance, which courts tend to consider persuasive but not binding (Zirkel, 2003), help to differentiate these various terms. For example, in the Commentary (2006) specific to RtI, which IDEA refers to as "a process which determines if a child responds to scientific, research-based intervention," USDE also expressed a marked preference for SBR with regard to the other two options for SLD identification:

\footnotetext{
The Department does not support the use of identification procedures that are not based on scientific research. Model or procedures that claim to assist in identifying a child with an SLD, but which are not based on sound scientific research, are not appropriate and should not be adopted by LEAs or States. (p. 46,648)
}

USDE's use of "support" and "should" in this comment merits special attention. The Department could not use "allow" and "must," respectively, in this context; it was constrained to preferring rather than requiring a scientific research basis for the other two options, for two respective reasons. First, the controlling legislative language in IDEA 2004 continued to permit rather than prohibit the severe discrepancy approach to SLD identification. Second, as a subsequent OSEP policy letter confirmed-in line with the binding language of the Department's final regulations-the third option must be "research-based" but not necessarily "scientifically-based" (Letter to Zirkel, 2008).

Similarly, as Zirkel and Rose (2008) covered in more detail, the Commentary explained that PRR "generally refers to research that is reviewed by qualified and independent reviewers to ensure that the quality of the information meets the standards of the field before the research is published," but the IDEA regulations do not provide a single, specific definition "because the review process varies depending on the type of information to be reviewed" (p. 46,664). At the same time, the Commentary differentiate PRR from "'evidenced-based practices' or 'emerging best practices,' which are generally terms of art that may or may not be based on peer-reviewed research" (p. 46,664).

Finally, as also delineated in Zirkel and Rose (2008), a consistent line of court decisions both before and after IDEA 2004 has rejected SBR as a requirement of the "free appropriate public education" (FAPE) obligation, and the limited litigation arising after the 7/1/05 effective date of IDEA suggested a nondramatic effect of PRR subordinated within the longstanding substantive standard for FAPE under Board of Education v. Rowley (1982).

\section{Resulting Outer Circles}

As a result, the approximate demarcation in Figure 1.1 of "research-based" and "evidence-based" amount to concentric circles that are successively broader in scope than the overlapping concepts of SBR and PRR. More specifically, "research-based" is broader than SBR because-like the third option for SLD identification-the terminology does not include the qualifier of being scientific, which would trigger the more specific and rigorous definition of SBR.

Similarly, "evidence-based" is broader than the other terms because it is a term of art that does not necessitate that the evidence be based on research, much less research that is scientifically based. In the context of litigation at leastthe focus of this differentiation- -evidence based" may include, for example, the documented results of continuous progress monitoring, teacher or other professional anecdotal reports, report cards, and professionals' testimony, whether expert opinion or not.

\section{CONCLUSION}

Although the lexicon, including the many acronyms, of special education is not entirely precise and consistent, the terms SBR, PRR, research-based, and evidence-based have legally differentiated meanings under IDEA. Following this differentiation-in which PRR and SBR are overlapping central concepts surrounded by the successive ambits of 
research-based and evidence-based-has the advantages of mitigating confusion and avoiding litigation, which are unintended potential consequences of using these legally significant terms loosely or interchangeably.

The terminology, like the law, is subject to change, particularly in the flux-like context of NCLB and IDEA. Indeed, our British counterparts already have introduced more nuanced terms, such as “' evidence-informed' and 'evidenceinfluenced' into the broader policy debate (Biesta, 2007).

In the narrower context of the current provisions of IDEA, however, it would seem advisable to focus carefully and distinctively in communications, and ultimately for litigation, on 1) SBR in LEAs that adopt RTI for identifying SLD, 2) "research-based" in LEAs that have chosen the third alternative -in states that have chosen to permit or require it (Zirkel \& Krohn, 2008)—for SLD identification, 3) PRR to the extent practicable in each IEP's specification of special education, and 4) "evidence-based" for their challenged practices more generally.

\section{REFERENCES}

Biesta, G. (2007). Why "what works" won't work: Evidence-based practice and the democratic deficit in educational research. Educational Theory, 57, 1-22.
Bd. of Educ. v. Rowley, 458 U.S. 176 (1982).

Commentary for the IDEA Final Regulations, 71 Fed. Reg. 46,54046,753 (August 14, 2006).

Crockett, J. B., \& Yell, M. L. (2008). Without data all we have are assumptions: Revisiting the meaning of a free appropriate public education, Journal of Law \& Education, 37, 381-392.

Graue, B. (2006). The transformative power of reviewing. Educational Researcher, 35(6), 36-41.

IDEA Final Regulations, 34 C.F.R. Part 300 (2007).

Institute for Education Sciences (IES). (2003). Identifying and implementing educational practices supported by rigorous evidence: A user friendly guide. Washington, DC: U.S. Department of Education. Letter to Zirkel, 50 IDELR II 49 (OSEP 2008).

No Child Left Behind Act (NCLB), 20 U.S.C. $\$ \S 6301$ et. seq. (2007).

Peer review under review at NIH. (2007). Educational Researcher, 36(6), 359-360.

Turnbull, H. R. (2005). Individuals with Disabilities Education Act reauthorization: Accountability and personal responsibility. Remedial and Special Education, 26, 320-326.

Zirkel, P. A. (2003). Do OSEP policy letters have legal weight? West's Education Law Reporter, 171, 391-396.

Zirkel, P. A. (2005). The over-legalization of special education. West's Education Law Reporter, 195, 35-40.

Zirkel, P. A., \& Krohn, N. (2008). RTI after the IDEA: A survey of state laws. Teaching Exceptional Children, 40(3), 71-73.

Zirkel, P. A., \& Rose, T. (2008). Scientifically based research and peer-reviewed research under the IDEA. Manuscript submitted for publication.

\title{
Shared Reading for Older Emergent Readers in Bilingual Classrooms
}

\author{
Tomás Enguídanos and Nadeen T. Ruiz
}

Historically, and continuing to the present, children in the primary grades receive the lion's share of attention and resources in learning to read. This makes sense: Young, early readers have a head start in achieving well not only in literacy skills but in school in general. However, as inner-city, middlegrade teachers will readily attest, emergent readers make up a part of their intermediate classrooms as well. The challenge, then, becomes providing effective early reading instruction to older students whose interests and motivation often differ widely from those of 5- and 6-year-olds.

We do not expect any of this to be news to special education teachers. Part of the charge of special educators has always been to work with older, struggling readers to help them become strategic, effective, and enthusiastic readers. The data on how well this goal has been accomplished are disheartening, however. Though there have been successes with individual students, the aggregated data do not show widespread improvement in reading and writing achievement of students in special education (Skrtic, 1991). The picture for special education students from culturally and linguistically diverse (CLD) backgrounds is even worse in terms of reading and writing test scores (Figueroa, 1992).

This article was adapted from New Ways of Looking at Learning Disabilities: Connections to Classroom Practice, published by Love Publishing Company, 2001. 
We focus our work as educators precisely in this area of literacy instruction for CLD students in general and special education. Both of us are associated with a literacy program called the Optimal Learning Environment (OLE) Project (Ruiz, Garcia, \& Figueroa, 1996; Ruiz \& Figueroa, 1995). Tomás teaches students with learning disabilities in a special day class and is a teacher leader with the OLE Project. Nadeen was involved in the OLE Project's inception in 1989 and has directed the project since 1994 (Ruiz, 1989, 1995a, 1995b). Together, we have trained many special and general education teachers throughout the southwest and in Mexico on how to provide CLD students with an optimal learning environment. We have also written together for our field. For example, we collaborated on an article about Arturo, Tomás's student, who at 9 years of age, began the year at the scribbling stage of writing and progressed within a few months under the OLE Project, to become a prolific writer of various genres, including poetry fashioned after the odes of Pablo Neruda (Ruiz \& Enguídanos, 1997).

In this article we share with you another product of our collaboration, an instructional strategy called Shared Reading for Older Emergent Readers (also known simply as Shared Reading). This strategy is one of a number of powerful techniques that we have found helps to move older emergent readers to fluency, comprehension, and enthusiasm and confidence as readers.

Nadeen begins the chapter by contextualizing Shared Reading within the research base underlying the OLE literacy program. She also points out that Shared Reading is only one of a number of instructional strategies associated with increased reading and writing achievement among students in OLE classrooms and should be used in conjunction with the other techniques to the greatest extent possible.

Tomás then shares, teacher-to-teacher, his classroom approach to using Shared Reading as he has developed it with the inner-city, Spanish-English bilingual students in his special day class. He begins by telling of his initial doubt regarding the appropriateness for his intermediate students of Shared Reading - an instructional strategy typically used with preschool and primary grade children. Tomás follows this with a classroom literacy story of reflection and change. Staying true to the theory and research behind using Shared Reading with emergent readers, Tomás has made the strategy an integral part of how he helps his older, struggling readers "break the code." Tomás details the procedures he uses so that others may implement this strategy in their own classrooms.

\section{RESEARCH ON EFFECTIVE LITERACY INSTRUCTION FOR LINGUISTICALLY DIVERSE STUDENTS IN SPECIAL EDUCATION}

In a number of publications I (Nadeen) have extensively reviewed the research base for literacy instruction for bilingual students in special education classrooms (Ruiz, 1995b, Ruiz, 1999). In all of these reviews, I noted the growing body of naturalistic studies, ones in which researchers have spent extensive time in classrooms looking for co-occurrence relationships between bilingual students' language and literacy performance and instructional contexts. Although the research has taken place in several different states, the convergence of findings is striking.

I found that four overarching principles have arisen from the classroom studies of bilingual students in special education that can guide us toward optimal instruction (Ruiz, 1999). In the following sections, I briefly explain these principles, linking them to the research base in both bilingual special education and second language education.

\section{Principle 1: Connect Students' Background Knowledge and Personal Experiences With Literacy Lessons}

Many studies of bilingual students in special education have noted that students improve their language and literacy performance when lessons tap into and build on their experiences and background knowledge (Echevarría \& McDonough, 1995; Flores, Rueda, \& Porter, 1986; Goldman \& Rueda, 1988; Graves, Valles, \& Rueda, 2000; López-Reyna, 1996; Rueda \& Mehan, 1986; Ruiz, 1995a, 1995b; Willig \& Swedo, 1987). That this finding has been validated many times over is not surprising, especially when it is viewed from a second language acquisition (SLA) perspective. Research on SLA has documented consistently that second language learners improve various aspects of their reading performance when their background knowledge is elicited or built up before they approach a text (Au, 1993; Barnitz, 1986).

\section{Principle 2: Foster the Use of Students' Primary Language (L1) in Literacy Lessons}

The rationale for using students' primary language for instruction is buttressed by studies in both bilingual special education (Echevarría \& McDonough, 1995; Flores et al., 1986; Goldman \& Rueda, 1988; Graves, Valles, \& Rueda, 2000; López-Reyna, 1996; Rueda \& Mehan, 1986; Ruiz, 1995a, 1995b; Viera, 1986; Willig \& Swedo, 1987) and bilingual general education (Greene, 1998; Ramírez, Pasta, Yuen, Billings, \& Ramey, 1991; Thomas \& Collier, 1996). In short, when instructed in their native language, bilingual students show improved language and literacy skills. Further, as shown by the bilingual general education studies just cited, these language and literacy skills transfer to the students' second language.

\section{Principle 3: Create Opportunities for Students to Meaningfully and Authentically Apply Their Developing Oral Language and Literacy Skills}

The research in both bilingual special education (Echevarría \& McDonough, 1995; Flores et al., 1986; Goldman \& 
Rueda, 1988; Graves, Valles, \& Rueda, 2000; López-Reyna, 1996; Rueda \& Mehan, 1986; Ruiz, 1995a, 1995b; Viera, 1986; Willig \& Swedo, 1987) and second language education (see reviews in Chaudron, 1988, and Tharp, 1997) has made an exceedingly strong case that language and literacy instruction for second language learners must begin in a meaningful context. Simply put, second language learners do poorer in instructional contexts in which oral language, reading, and writing are removed from any real communicative intent and in which reading and writing are formatted into drills and worksheets. Second language researchers and teachers have known this anecdotally since the failure of the drill-oriented second language methods of the 1960s and 1970s, and empirically since the late 1980s (Chaudron, 1988). The bilingual special education studies cited earlier have also validated this for second language learners in research beginning in the 1980s and continuing to the present.

This principle is an extremely important one in the face of current literacy instruction trends. National media have pushed a reading instruction agenda that highlights decontextualized phonics as a way of reversing underachievement in reading. They repeatedly cite an unpublished manuscript by Foorman and colleagues (SRA McGraw-Hill, 1996) which purportedly showed that for an ethnically diverse group of general education students a decontextualized, systematic phonics program worked best in terms of their reading achievement. The Foorman study, however, is so flawed that drawing any strong conclusions from it is suspect. (See Taylor, 1998, for a thorough analysis of the Foorman study.) Most important, because of its flaws, it does nothing to counter the research from bilingual special and general education. Unlike the researchers listed earlier, Foorman did not identify which of her Hispanic subjects were Spanish speakers, nor did she provide information on their place of birth, age on arrival to the United States, languages spoken at home, or language proficiency in English and Spanish. Even the most rudimentary study of bilingual students includes this sort of information, given its impact on language and literacy achievement. Consequently, the research base for a meaning-driven literacy curriculum for second language learners in both special and general education remains uncontested.

\section{Principle 4: Foster Increased Levels of Interaction (Oral Language, Reading, and Writing) Among Students and Teachers}

Many studies in the bilingual special education area have explored what happens when teachers reverse the patterns of student passivity typical of remedial classrooms and instead organize their classrooms into highly interactive language and literacy settings (Echevarría \& McDonough, 1995; Flores et al., 1986; Goldman \& Rueda, 1988; Graves, Valles, \& Rueda, 2000; Gutiérrez \& Stone, 1997; López-Reyna, 1996;
Ruiz, 1995a, 1995b; Willig \& Swedo, 1987). All of these studies share a common conclusion: Students experience greater growth in language and literacy skills when they can actively initiate extended turns of oral language, reading, or writing or when they can collaborate with others in classroom literacy events. The literature from second language instruction validates this principle, with multiple studies showing the advantage of collaborative contexts for language and literacy as opposed to teacher-dominated, student-passive contexts (TESOL, 1997).

Special educators looking to reverse the underachievement trends among bilingual students would do well to incorporate these overarching principles in designing effective literacy programs for their students. A few literacy projects have already heeded this research base, such as AIM for the BEST, developed at the University of Texas at Austin (Ortiz, Wilkinson, Robertson-Courtney, \& Kusher, 1991). In the following section I describe another such project-the Optimal Learning Environment Project located at California State University Sacramento-which provided the context for Tomás's and my collaboration.

\section{RESEARCH-BASED, EFFECTIVE LITERACY INSTRUCTION: THE OLE PROJECT}

The OLE Project is a program of balanced literacy instruction for culturally and linguistically diverse students in general and special education (Ruiz, García, \& Figueroa, 1996). The project began in 1988, when the California State Department of Education asked a team of researchers to address the underachievement of Latino students in special education (Figueroa, Ruiz, \& Rueda, 1988). Using the four principles described earlier, as well as others derived from the areas of bilingual education and second language education, the project identified 12 optimal conditions for effective literacy instruction of bilingual students (Table 2.1). The project then identified instructional strategies that helped to create those optimal conditions in classrooms. Subsequently, the OLE Project was further encouraged to include general educators in its trainings, given the finding that special education students sometimes returned from an accelerated, enriched, OLE special education classroom to a very remedial, instructionally poor, general education classroom (Ruiz \& Figueroa, 1995).

The instructional strategies that the OLE Project currently emphasizes in its trainings are the following: Interactive Journals, Roll-Call Variation (phonemic awareness and early phonics activities), ABC Wall Charts, Shared Reading, Guided Reading, Literature Study Circles, Drop Everything and Read Time, Shared Writing, Creating Text With Wordless Books, and Writers' Workshop. However, this list is very dynamic. At the core of the OLE Project are the research-derived optimal conditions. As long as a proposed 
TABLE 2.1

Shared Reading as Part of an Optimal Learning Environment

\section{Optimal Conditions for Learning}

\section{Student Choice}

Students exercise choice in their learning when possible, such as by selecting writing topics, books, research projects, and thematic cycles.

\section{Student-Centered Instruction}

Lessons begin with and revolve around students' personal experiences, background knowledge, and interests.

\section{Whole-Part-Whole Approach}

Lessons begin with whole texts (e.g., books, poems, newspaper articles) to maximize the construction of understanding, then move to the analysis of smaller units of language forms (e.g., phonics, spelling, punctuation), and then return to the text as a whole.

\section{Active Participation}

Students actively engage in lessons with frequent and long turns of talk.

\section{Meaning First, Followed by Form}

Students construct meaning from (reading) or through (writing) text first, then move to a focus on correct forms of language such as spelling and grammar.

\section{Authentic Purpose}

The end products of lessons have a real-life function that often extends beyond the classroom; There are real audiences and real purposes.

\section{Approximations}

Students are encouraged to take risks and successively approximate language and literacy skills (following a developmental course).

\section{Immersion in Language and Print}

The classroom is saturated with different print forms and functions and with opportunities to hear and use language for a wide range of purposes.

\section{Demonstrations}

Teachers demonstrate their own reading and writing and share their ongoing efforts with students.

\section{Response}

Students receive timely responses to their oral and written texts that go beyond letter grades to personalized and thoughtful acknowledgements of their ideas, experiences, and efforts.

\section{Community}

Students, parents, and teachers form a community of readers, writers, and learners who explore a range of questions relevant to them.

\section{High Expectations}

Teachers, parents, and the students themselves expect that the students will become proficient and independent speakers, readers, and writers.

\section{How Shared Reading in Tomas's Class Creates Optimal Conditions}

Students negotiate the choice of poems that they will work with during Shared Reading. They select sections of poems that they connect with and want to discuss. They choose how and what to write in, for example, their reflection journals.

Tomás often introduces the poems by eliciting or building up relevant background knowledge. Students immediately make personal connections with lines of the poems.

Poems and songs constitute the primary texts for Shared Reading. Once students understand them, Tomás "decontextualizes" the texts by separating them into smaller units of language-words, phonemes, graphemes, onset/rimes, affixes, etc.- -and uses smaller units to teach word recognition and spelling skills.

Students must explain their choices, personal connections to, and opinions about the texts to the learning community. They chorally reread the text many times.

Tomás first works on comprehension of the poems and the students' personal responses to them. Then he emphasizes the decoding and spelling aspects of texts, working on soundsymbol correspondences, onset and rime patterns, spelling, etc.

Tomás and his students may create an innovation on the poem or song's pattern, their own class book, or a performance to be shared with people outside of the classroom.

In their reflection journals or in creating their own poems, students write at their own developmental level (e.g., prephonetic, transitional, etc.). Tomás selects developmentally appropriate reading skills as his focus in skill lessons with the texts.

From the initial stage of selecting the poems from the classroom walls, students see writing, often their own, posted throughout their room. This writing includes evidence of systematic phonics instruction.

Tomás explains to his students how he initially selects many of the texts through his own extensive reading of poetry. He also shares his own poetry writing.

During Shared Reading, Tomás and his students come together daily to share and discuss their reading and writing. The students organize a special evening where they demonstrate Shared Reading for their parents.

Throughout all phases of Shared Reading, students receive immediate feedback to their orally-expressed ideas and written reflections. These responses constantly push the students toward more advanced language mechanics and deeper content.

Tomás expects that all of his students will learn to decode and comprehend the different texts used for Shared Reading and will transfer those skills to other literacy events. 
instructional strategy helps to create most of the conditions in the classroom, we consider its use with our students.

To make clear the OLE Project's strong link between theory and practice, I now describe generally the instructional strategy Shared Reading, the focus of this chapter, and show how it helps to create optimal conditions for bilingual students' literacy learning.

\section{SHARED READING AS A LINK BETWEEN CLASSROOM RESEARCH AND PRACTICE}

In 1979, Don Holdaway, a literacy researcher from New Zealand, coined the term Shared Reading. He had spent months observing primary teachers approximate in their classrooms what has been called the "bedtime story routine," that is, the routine in which a parent and child interactively read and talk through a book. The teachers in Holdaway's teacher study group had developed a way of modifying this typically one-on-one routine to accommodate their classrooms full of children (Holdaway, 1982). One especially helpful modification was to use enlarged texts so that all children could see both the print and the pictures as the teacher and children co-constructed meaning from the text. The current proliferation of Big Books in primary classrooms is a direct result of Holdaway's work with teachers.

Researchers established years ago the relationship between a bedtime story routine and early development of literacy. In such a literacy event, children build up their knowledge of story structure, "booklike" talk, connections between texts and the world, concepts about the way print works, phonemic awareness, and even early word recognition skills - all important precursors to independent reading. Primary teachers can quickly pick out those students who have been read to frequently and intensively. But it is equally clear that not all children have had the same access to books and literacy events, making Shared Reading critically important to establish as a classroom routine.

The OLE Curriculum Guide (Ruiz, García, \& Figueroa, 1996), as well as almost every current reading methods textbook, contains a section describing traditional Shared Reading procedures. Briefly, the teacher introduces a book by conducting discussions about the cover's pictures and title and inviting the students to predict the story's content. In this introductory phase, the teacher also attempts to have students personally connect to the book. For example, in introducing a story about a lost duckling, a teacher may say, "Before we begin to read this story, let me ask whether any of you have ever been lost. How did that feel? What did you do?" The teacher then begins to read the book to the students, continuing to elicit predictions and personal connections throughout. At the end of the first reading, the teacher and students discuss their reactions to the book. Then, rather than shelving the book, the teacher rereads it on subsequent days, following the readings with developmentally appropriate lessons on literacy skills and strategies. These lessons can focus on phonemic awareness, phonics, punctuation, sight words, and so on. To make these rereadings attractive, teachers seek out books with texts that are conducive to choral rereadings, such as rhyming texts and texts with repetitive patterns that are fun to read aloud.

In a nutshell, Shared Reading creates the opportunity for all students to develop key early literacy skills listed above in a highly interactive context with the support of more expert readers such as the teacher and, often, other students. It is a very "dense" literacy strategy given both the long list of skills that it teaches (it is difficult to call to mind a prepackaged, remedial reading kit that could promise the same) and its connections to literacy acquisition theory (e.g., Vygotsky's observations (Moll, 1992) that language and literacy development occur first on the interpersonal plane, with assistance from a more expert person, and then on the intrapersonal or independent level of performance).

The OLE Project selected Shared Reading as one of its key literacy strategies based on how it has helped teachers to create the 12 optimal conditions the project identified for effective literacy instruction of bilingual students. The ways in which Shared Reading facilitates these conditions are described in Table 2.1. The table also describes Tomás's application of Shared Reading with his older emergent students in special education as a means of both explicating the link between classroom research and practice, and previewing Tomás's description of his modification of traditional Shared Reading.

\section{IMPLEMENTING SHARED READING FOR OLDER EMERGENT READERS}

Why implement Shared Reading with poetry? A teacher recently told me (Tomás), "I don't think I even like reading poetry myself." For many people, experience with poetry in school has not been particularly positive. We are given poems to read from a textbook and we answer the questions at the end of the selection without connecting to the poem. In most cases, there is little choice of material to read. And after we read the poem and answer the questions, the wellmeaning teacher or professor begins to interpret the poem's meaning according to literary criticism. I think that poets likely find this humorous or preposterous. As a student, I always had my own interpretation that I tried to defend, but my reaction or what I brought to the poem as the reader was often considered less than valuable. I always found this mysterious and frustrating.

When I began working with the OLE Project, I avoided the strategy of Shared Reading, because the predictable texts that were traditionally used with this strategy were written for emergent readers in early elementary grades. I 
worked with older emergent readers in upper elementary and felt that the predictable texts were belittling to my students. I didn't want to talk down to them. Nadeen challenged me to find texts that were appropriate for my students, because she felt they really needed the balanced approach to reading skills and reading strategies that shared reading offered. One day in a workshop, she began a Shared Reading talk with Maya Angelo's "Life Doesn't Frighten Me." Nadeen introduced the poem with an incredibly frightening and moving story of a time when she and her family witnessed an armed robbery in a convenience store. Maya Anglelo's chilling poem further made my hair stand up on the back of my neck. I saw that the poem is predictable with rhyming and repetitive text yet has a theme to which my students could connect, because of all they see and have become accustomed to as inner-city youth. I was inspired (as I so often am by my colleagues in OLE) to try the poem out on them. Here was a predictable text that I could bring to life in Shared Reading. The strategy that I now use in my classroom began with and evolved from working with this poem.

As I dove into poetry, inspired by Nadeen's workshop I began to see the poetry in everyday life. I realized that it existed in the moment when Nadeen witnessed the robbery. I saw that the street has a rhythm as I walk to lunch each day. The sights, the sounds, the smell, the textures, all of these come together in poetic elements, images, and moments. As I began to view the images that were present in the moments in my life, I realized that these were symbols of all that I must learn. They were symbols or signs that life had placed before me. The images of daily life for the poet are the potter's clay, the carpenter's wood (see "Poetic elements" later in this chapter).

We all have poetry in our lives. It is in the symbols placed before us that to each of us have a unique set of meanings and connections, if we open our eyes, ears, and hearts. We are touched. This is the muse, or inspiration.

Octavio Paz, in a book titled El Arco y la Lira, discussed the confusion that exists between poetry and poems. He wrote that there is poetry without poems; a landscape, people, and occurrences can be poetic. They are poetry without being poems. When poetry is seen as a condensation of chance or a crystallization of forces and circumstances independent of the will of the poet, we encounter the poetic moment. When, either passively or actively, awake or dreaming, the poet is the conductive wire and transformer of the poetic current, we are in the presence of something entirely different: a poetic work. For these reasons Paz stated that a poem is not a literary form but rather the encounter between "man" and the poetic moment.

We all encounter poetic moments in our lives. Bringing poetry into the classroom and sharing its vivid language with our students gives voice to the poetic moments each of us has experienced. The poet's voice models precise language for describing the students' own experience. I use these texts because they are age-appropriate-and motivational.

\section{Management}

In a typical week in my classroom Shared Reading fits into two parts of our daily classroom management routine. First we begin each day with our morning community circle in which poems or songs are introduced to the students. This daily celebration of the language of poets and song-writers sets a tone for creative use of language and leads to the selection on Friday of one poem or song for the following week's in-depth study in the Shared Reading With Poetry literacy center. The poem which students help to select is studied in the literacy center for five days. Figure 2.1 shows where in the daily class schedule the teacher might fit both Circle Time and Literacy Center rotations. The Shared Reading With Poetry Literacy Center weekly plan is detailed in figure 2.2. A center activity typically lasts for 40-50 minutes. Our centers have included Shared Reading With Poetry, Interactive Journals, and Writer's Workshop rotating with Drop Everything and Read (independent reading) or literature studies extension activities.

Figure 2.1 provides a general view of our week. Depending on the time of year and where our studies have led us, we might put more emphasis on literature studies and Writer's Workshop and less on Shared Reading of Poetry and Interactive Journals.

\section{Selecting Poems, Songs and Poets}

If Shared Reading With Poetry and Song is to be implemented there need to be some structures in the classroom for selecting poems and songs, having students react to them, and for in-depth study of the selected pieces. The following list illustrates structures I have used during circle time to select poems for later in-depth study in the "Shared Reading With Poetry" Literacy Center. These structures are described in detail in the following sections. The structures include:

1. Circle Time Read Aloud

2. Round-Robin Read

3. Sing Along

4. Drop Everything and Read (DEAR Time)/Poetry Dig with poetry mini-lesson

\section{Circle Time Read Aloud}

It is important to make the language of poetry a regular part of your day with your students. In my class, I try out new poems and songs in the morning during circle time, introducing at least one a day. The circle is an intimate place in our classroom, where the students and I share the ups and downs of our lives. We may bring in favorite books, poems, 


\begin{tabular}{|c|c|c|c|c|c|}
\hline $8: 40-9: 00$ & $\begin{array}{l}\text { Community } \\
\text { circle/poem } \\
\text { or song }\end{array}$ & $\begin{array}{l}\text { Community } \\
\text { circle/poem } \\
\text { or song }\end{array}$ & $\begin{array}{l}\text { Community } \\
\text { circle/poem } \\
\text { or song }\end{array}$ & $\begin{array}{l}\text { Community } \\
\text { circle/poem } \\
\text { or song }\end{array}$ & $\begin{array}{c}\text { Community } \\
\text { circle/poem } \\
\text { or song selection }\end{array}$ \\
\hline $9: 00-9: 20$ & $\begin{array}{l}\text { Daily news/ } \\
\text { shared writing/ } \\
\text { mini-lessons }\end{array}$ & $\begin{array}{l}\text { Daily news/ } \\
\text { shared writing/ } \\
\text { mini-lessons }\end{array}$ & $\begin{array}{l}\text { Daily news/ } \\
\text { shared writing/ } \\
\text { mini-lessons }\end{array}$ & $\begin{array}{l}\text { Daily news/ } \\
\text { shared writing/ } \\
\text { mini-lessons }\end{array}$ & Library \\
\hline $9: 20-10: 00$ & $\begin{array}{l}\text { Rotation } 1 \\
\text { literacy } \\
\text { centers }\end{array}$ & $\begin{array}{l}\text { Rotation } 1 \\
\text { literacy } \\
\text { centers }\end{array}$ & $\begin{array}{l}\text { Rotation } 1 \\
\text { literacy } \\
\text { centers }\end{array}$ & $\begin{array}{l}\text { Rotation } 1 \\
\text { literacy } \\
\text { centers }\end{array}$ & $\begin{array}{l}\text { Rotation } 1 \\
\text { literacy } \\
\text { centers }\end{array}$ \\
\hline $10: 00-10: 40$ & $\begin{array}{l}\text { Rotation } 2 \\
\text { literacy } \\
\text { centers }\end{array}$ & $\begin{array}{l}\text { Rotation } 2 \\
\text { literacy } \\
\text { centers }\end{array}$ & $\begin{array}{l}\text { Rotation } 2 \\
\text { literacy } \\
\text { centers }\end{array}$ & $\begin{array}{l}\text { Rotation } 2 \\
\text { literacy } \\
\text { centers }\end{array}$ & $\begin{array}{l}\text { Rotation } 2 \\
\text { literacy } \\
\text { centers }\end{array}$ \\
\hline $11: 40-12: 10$ & $\begin{array}{l}\text { Literature } \\
\text { studies }\end{array}$ & $\begin{array}{l}\text { Literature } \\
\text { studies }\end{array}$ & $\begin{array}{l}\text { Writer's } \\
\text { Workshop }\end{array}$ & $\begin{array}{c}\text { Writer's } \\
\text { Workshop }\end{array}$ & $\begin{array}{l}\text { Computer lab } \\
\text { scanning }\end{array}$ \\
\hline $12: 10-12: 50$ & Lunch & Lunch & Lunch & Lunch & Lunch \\
\hline $12: 55-1: 10$ & Read aloud & Read aloud & Read aloud & Read aloud & Read aloud \\
\hline $1: 10-1: 50$ & Math & Math & Math & Math & Math \\
\hline $1: 50-2: 30$ & Science & Social studies & Science & Social studies & Science \\
\hline
\end{tabular}

\section{FIGURE 2.1 Daily Class Schedule}

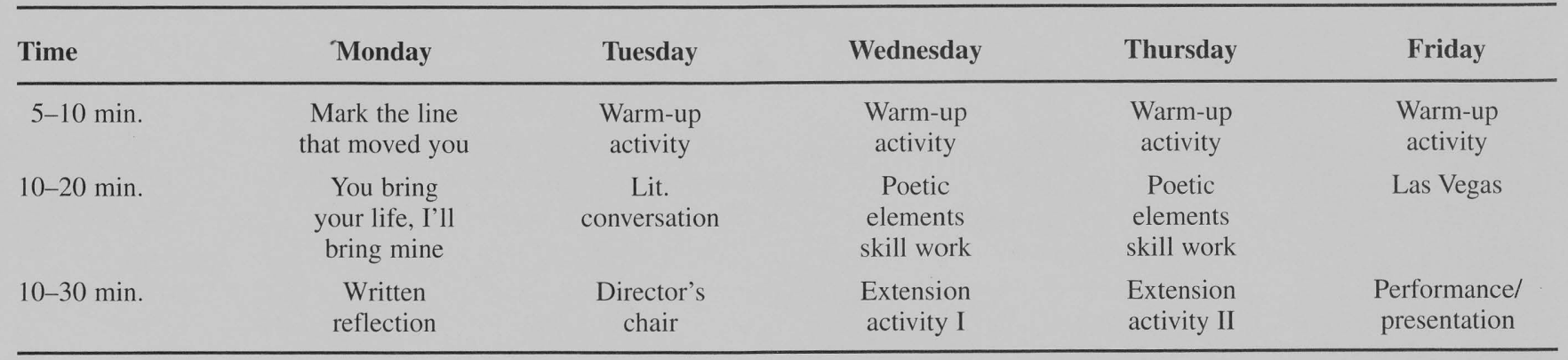

FIGURE 2.2

A Week in the Shared Reading With Poetry Literacy Center

and songs to share, including works in progress of our own creation. It has become a ritual that we always do the first thing in the morning. Sometimes we call an impromptu circle at other times of the day as well. The important thing is to have a predictable time to celebrate the unpredictable language of poetry time to bring our voices and hearts together in a song.

\section{Round-Robin Read}

Another effective means of sharing poetry is to invite two or three other adults into the circle to join you in reading poems to the children. You and the other adults are each armed with two or three poetry books, and you trade off reading, one person at a time. If you and the other adults aren't prepared ahead of time, just prior to circle time you can all skim through the books and mark several that you wish to try. Then you can simply give them a go off-the-cuff. It's a fast paced whirlwind of poetry that is contagious. The students get caught up in listening and responding. You can really tell which poems grab them and which fall flat. It helps if the adults are comfortable reading poetry and read with expression. Some people prefer more rehearsal time. I 
know that I sometimes get nervous reading in front of the other adults. I try to overcome this by diving into the poem and feeling the words and rhythm.

\section{Sing Along}

I've been a musician for years, but until we started working with Shared Reading I hadn't tapped into the power of songs for teaching reading. Music is a natural way to learn language in a soothing or an exciting and rhythmic, way. By sharing your own musical tastes or talents (e.g., your favorite compact disks or tapes), you open the door to a rich poetic form for Shared Reading. You can invite local musicians to join you and collaborate. You and the students can transcribe the lyrics and study what songwriters have to say. You can engage the class in singing: It's a great way to center your class in times of stress, to celebrate the "dance of joy" of life, and to teach reading on the sly.

There are many wonderful songs that can be used with shared reading strategy. Children love to sing, and singing helps them to memorize words. Once memorized, the words can be worked with out of context, focusing on word recognition and other skills. In Latin music it is not unusual to find songs that come directly from the words or inspiration of Latin poets. Indeed, many poems (including those in English) have a rhythm that can be sung naturally. We sometimes sing, chant, or rap poems to practice reading them.

There are many web sites dedicated to song lyrics. Here are a few of my favorites:

http://www.lyrics.ch/

http://condorito.metro.msus.edu/artistas.html

http://www.uclm.es/ jaiglesi/

http://www.geocities.com/CapitolHill/6590/index.html

http://spin.com.mx/ luisg/Pablo/

http://planetx.bloomu.edu/\%7Egmalbert/songlyrics/

http://tinpan.fortunecity.com/petebest/10/lyrics.html

http://www.deltablues.com/blues.htm

http://www.superior.net/ jimligon/lyrics/Rhythm_and_Blues/

http://www.fiftiesweb.com/lyrics/lyrics.htm

Rap musicians are the poets of today's youth. I personally like rap, although I have trouble reconciling the feelings many of the songs evoke. I know of family members of students, current and former, who have been gunned down by the violence of the streets. Rap music often glorifies this violence, but I believe it also lays bare what is happening to many young people. I ask my students to bring in music that they would like to study. Sometimes we get into conflicts about the lyrics. My ground rules are that the songs cannot disrespect women, disrespect people's lives, or promote violence. I also rule out songs that contain language that is inappropriate for school. My students, however, have struggled with these limitations. They feel the songs I've ruled out tell the truth, and they like them. They tell me that I said they could bring in their favorites. They feel I am censoring. We have good discussions about these issues. I can honestly say that I haven't resolved them for myself. Nor have I explored the genre to its fullest extent. The following is a link to hip-hop lyrics: http://www.ohhla.com/index.htm.

\section{Dear Time With Mini-Lesson/Poetry Dig}

Drop Everything and Read (DEAR Time) mini-lessons are short, 3-15 minute lessons that help guide students toward becoming excellent independent readers. The lesson can come at the beginning of DEAR Time, which is an independent reading period of about 15-20 minutes. The lesson can be on a specific type of poem, a poetic theme, a poetic element, or a poet. In the lesson you may model how it is that you find poets and poems that are meaningful to you as a reader: You can focus on how you read poetry, on what makes a particular poet your favorite, on what you would like to see the students doing with a partner or a group of friends as they immerse themselves in this genre. You can read poetry or compare and contrast poets and their poetic works.

Another strategy I use to get students immersed in poetry is the Poetry Dig. I have found that students are most eager to explore poetry books when the books and poems are arranged in an inviting way. I have a poetry section in our classroom library. But when I want to focus the children specifically on poetry, I arrange the poetry books in the library in tubs or on tables. I also provide access to poems previously studied through pocket chart versions (described later in this chapter) and through having available a large box of poems written on butcher paper.

\section{Gallery Walk}

A fun way to immerse students in poetry (poems) and at the same time form working groups for in-depth poetry study is to conduct a Gallery Walk. In a Gallery Walk, the class peruses poetry on the classroom wall just as they would enjoy art in an art gallery.

There are many options for choosing the poems the students will read and discuss during the Gallery Walk. One option is to select poems that the students have heard and responded favorably to but have not yet studied in an indepth way. Another option is to introduce new poems of a favorite poet students have already enjoyed. Because my students have needed help with reading the poems, I have had an adult or strong student reader stand at each poem to help the students enjoy them.

After the students have read all of the poems, I instruct them to group around the poem that most affected them, their favorite, or the one they would most like to study. The rule is that no more than four to six students can gather in front of any one poem. Although it is possible to use a different 
number of students, I have found that groups of four to six students are most effective, as they promote equitable and active participation for each student. My students have respected this limit without much grumbling, although sometimes we have to negotiate. It is most important that the students understand that they are selecting a poem for in-depth study and that each student must be prepared to contribute.

I instruct my students to attach a Post-it to the poem, indicating their name and the part of the poem that attracted them or made them react. Their comments on the Post-it will later help guide their written reflection and literature conversation, and the names listed help me keep track of who is working on each poem.

The groups of students then meet to discuss why they chose their particular poem. This is a form of an inclusion activity, since the students form affinity groups around a piece of good literature. They also tend to have deep conversations that lead to a deepening sense of community. In addition, it is a natural language lesson, because the students must put their feelings into words. In doing so, they act as models for one another. I have had an adult at each poem to facilitate the discussion and model the type of introspective response to the poem that I am looking for (i.e., "You bring your life, I'll bring mine"). However, I have found that once the students have learned the type of response I am after, they tend to want to facilitate their own discussion. This is good. When all have had a chance to share, the group members are instructed to go off individually to write, draw, and reflect in their poetry journals. These written reflections are enriched by the discussion they have had and are used for later activities, conversations, and creativity (writing, dramatizing, artwork, movement, etc.).

Following their reflection, we ask the students to go back to the poem and talk about what made the poem work for them (stylistic elements, imagery, rhythm, sound elements etc.).

\section{ELICITING PERSONAL REACTION/ CONSTRUCTING MEANING}

What the reader brings to a poem is an essential part of the life of the poem. One's initial reaction leads to the discovery of poetic moments in one's own life. These moments are the source of inspiration for in-depth poetry study. They also inspire the emerging reader to take risks as a reader and writer.

\section{Marking the Part of the Poem That Moves You: "You Bring Your Life, I'll Bring Mine" (Monday 5-10 Minutes)}

As just noted, each of us brings to a poem a poetic moment that connects with that of the poet. In Shared Reading, the teacher and other adults serve as facilitators or guides to the search for that moment, a moment in each student's life that he or she connects with the poem. I ask my students questions to elicit what they felt when hearing the poem as well as what they felt in their own poetic moment. I ask for examples from their lives that will help me and the class feel what they felt as a reader. Responding is at first difficult for some. But with practice, my students have learned to dive into both the poem and their lives. They stretch their vocabulary to try to put into words what they experienced and felt. They use the text as a fountain from which to draw fluid language, and they begin to approximate the language of the poet to describe poetic moments in their own lives.

Lauren O'Leary, a speech and language specialist who has collaborated with me during Shared Reading, was amazed at the depth of language she observed my students in a bilingual third- to fifth-grade Spanish bilingual class use during these discussions. As a result, she encouraged the deaf education teacher, Bea Worthen, to try the strategy with her deaf students. She related the following to me about how she and Bea conducted Shared Reading with poetry with these students:

\footnotetext{
Bea and I talked [with the students] about what the overall poem meant to us (surprise, surprise, totally different interpretations), then picked our favorite lines, explained why, then requested the students do the same. I expected that the one fifth-grade student, Jasmine, would probably be able to make some kind of response that made sense but was not expecting anything too deep. With the other students, I was expecting off-the-wall responses, and that we would have to do pretty heavy-duty scaffolding with them to get a response that made some kind of sense. Then, much to our shock, as each student got up and made a response, not only did the responses make sense; they were beautiful and moving. The last student to get up was Nina (a student labeled with severe learning disabilities, attention deficit disorder, cerebral palsy, and deafness). She walked up to the chart, pointed to the word "green," and signed "green." She was very happy with herself. Bea and I congratulated her on knowing the word, and she went back to her seat. Jasmine was irate! She said to us, "That's not right. She's supposed to tell why she liked that line, not just read a word." We said something back to her to the effect that it was all right for Nina to just read the word, but Jasmine refused to accept that. Jasmine then started scaffolding for Nina, saying "Why did you pick that word? Is it because you like grass, and grass is green? Or is it because you don't like green things? Or why?" Nina then signed back, "No, favorite." Later, checking back with Pat (Nina's mother), it turned out that green was her favorite color. That was a turning point for me, because prior to that lesson, I was not certain of the student's capacity for higher order thinking. After that, both Bea and I realized that although they had a lot of syntactic difficulties and limited vocabulary in signing, there was a lot going on inside their minds that we had not been giving them the opportunity to express. It was a revelation. (from an e-mail correspondence from Lauren O'Leary)
}

\section{Written Reflection (Monday 10-30 minutes)}

After this initial discussion of the poem, everyone writes a reflection. Students and teachers can go deep into the 
thought and feelings, the memories, that the poem evoked in this reflection. I believe that this type of reflection is a tool we use to find our own voice as writers. With the help of expert writers, we dive into the important themes in our life and see what we uniquely have to say. Often, the students begin to approximate the language of the poet. Often, they go deeper than we imagined they could go. We just need to set up the proper conditions for this to occur.

\section{Conversation/Literature Circle (Tuesday 10-20 Minutes)}

The written reflections help the students to deepen their conversation about the poem. So, as a next step, I have the students take turns sharing where their reflections have taken them. The conversation is similar to other Literature Study Circle conversations (see the OLE Curriculum Guide [Ruiz et al., 1996] or Harvey Daniel's 1994 Literature Circles). As each student takes a turn, the other students are to actively listen, question the speaker, and make connections to their lives and to other literature. After all the students have shared, I facilitate another look at the poem, helping the students to find a direction for further work with the poem. If, for example, one student's connection to a poem is particularly strong, with vivid images from a moment in his or her life, then I might ask that student to be the director in Director's Chair (see next section).

\section{Director's Chair With Response From an Audience (Tuesday 10-30 Minutes)}

Some student responses to poetry and songs are so vivid and moving that they easily lend themselves to dramatization. The moment of feeling and inspiration that a poem evoked in a reader, the poetic moment for that reader, serves as a starting place for dramatizing the feeling of the poem. I have the student who seems most connected to the feeling of the poem, or the most inspired, lead the way. This student becomes the director of the activity (I am the executive producer). The student, using his or her written reflection or the part of the poem he or she selected as a prompt, initiates a casting call. The student tells the other students how many actors are needed and asks for volunteers for each role. It's the director's vision of the poem that will be brought to life, so he or she has to be able to describe to each character how to play the part.

In this activity, the audience plays an active role in helping the actors and the director to improve their performance. The audience members keep notes on strengths and areas that need improvement in the performance, and after the director gives the actors feedback, the audience is invited to share their notes with the actors. We use visual prompts to guide these comments - visual gauges with scales of 1-10 to help give actors feedback (see Figure 2.3). If, for example, our focus is

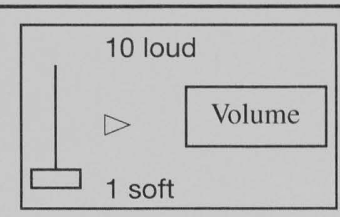

Volume, pitch, tension, and timing are important frames of reference for performers, whether speaking, singing, moving, or making sound effects. With a visual poster of adjustment knob settings, students can easily direct one

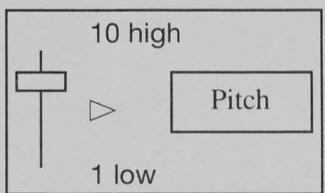
another with immediate feedback. The settings can range from $1-10$.

At times, students are either too loud or too soft in their presentation. The class can suggest raising or lowering the volume.

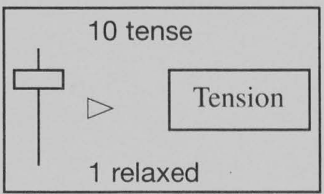

- In adopting voices for presentations, students often change the tone or pitch of their voice. The class can suggest deepening or lowering the pitch.

- Tension refers to either body tension or mood of expression. At times, students speak in a calm voice when the words actually call for rage, sadness, or passion.

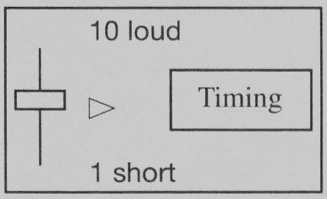
call for rage, sadness, or passion.

Timing can refer to movement o to the speed in which a student speaks or reads a passage.

\section{FIGURE 2.3 \\ Scaffolding for Group Feedback in Director's Chair and in Other Performances (Tuesday)}

on clarity of expression, the students give feedback in terms of the actor's performance volume, pitch, tension, and timing. A similar structure can be used for feedback on any type of class presentation or performance. The teacher can elicit from the class criteria for excellence in performing, and the students can then hold one another to those standards.

\section{SKILL WORK: DAILY PRACTICE (5-10 MINUTES)}

\section{Warm-Ups}

After having immersed ourselves in a poem and reacted to it according to our personal experiences, we play games with the words and phrases in the poem. These games include "find a word" games and reading games that encourage the students to read phrases in the poem aloud with varying interpretations of the feelings the words convey. These games are described in the following sections.

\section{Initial and Final Sounds/Blends. (Warm-up Activity)}

In daily warm-ups and later in pocket chart reading (described in a later section), I begin by asking the students to point to certain words of the poem and read them. It's good to have Post-its for the large chart on which the poem is written and pieces of oak tag for the pocket chart, so that 
you can isolate certain parts of the word and encourage the students to sound them out. In Shared Reading, we work whole-part-whole (see Table 2.1, Condition 3), and now is when I jump into the fragments of the poem.

\section{Find a Word (Warm-up Activity)}

Children seem to enjoy the challenge of finding words within a body of text. Depending on the developmental level of the student, the game may focus on beginning and ending sounds, words that have combinations of sounds (word families), or grammatical categories of nouns, verbs, adjectives, and so forth. In some cases, I give a definition of a word for a word search, so the students can develop their vocabulary while playing Find a Word.

With these games, the students overcome their fear of the written word and use a variety of cues to find the word you are asking for. Some rely mostly on visual cues, while others "read" the whole piece by memory, stopping at the correct word. Still others use the context to find the part of the poem in which they remember hearing the word used and thus narrow their search. Then they switch to visual cues. I make these cues explicit by celebrating the strength of each attempt, similar to the way I discuss solving math problems. This activity is quite revealing in showing the students' strengths as readers.

\section{Phrase Mirroring (Warm-up Activity)}

Linda Carr, choreographer and dancer for the Performance Arts Workshop in San Francisco, helped us to focus on our reading of a poem. Knowing that the tone with which we read a poem affects our ability to reach an audience, she helped the students practice reading poetry by showing them a mirroring game involving partners. One partner faced the poem and read a line of the poem while the second partner, standing with his or her back to the poem, faced the reader and mirrored or repeated the performance of the line. If the reader felt that he or she had been mirrored precisely, then they would switch places and start the game again. We found that this game increased reading fluency. As students got into their interpretive reading they forgot their fear of reading aloud. They also became more expressive readers.

\section{Dancing/Choreography/Movement}

Also with the support of Linda Carr, we found that words and phrases or sections of poems could be expressed nonverbally through movement. She took us through the warm-up activities that are usually associated with dance and theater and connected these to our study of literature, especially poetry. This required daily practice and discipline on the part of all of us. Linda celebrated when one of the students captured a poetic moment with clarity. These warm-ups led to students choreographing performance art with poetry.

\section{Las Vegas (Reconstructing the Poem in the Pocket Chart). (Friday)}

"Las Vegas" is a name I have given to a game involving pocket chart reading (see OLE Curriculum Guide [Ruiz et al., 1996]). I write the words of the poem on oak-tag strips, cut them apart, and place one line of words per pocket. I tend to work with one verse at a time; however, I attempt to provide one line per child. That is, I ask each student to be responsible for facilitating the reconstruction of one of the lines. To begin the game, I deal the words for one line to the students, who are sitting around the table like they are playing a card game. The student-facilitator for the line says the words of the line, one at a time, and asks the participants to look at their cards to see if they can find the word. The student who has the word comes to the chart and places it in the appropriate pocket. Only one student may come to the chart at a time. Student errors are viewed as teachable moments. I refer the student who made the error to the initial and ending sounds of both the word on the card he or she placed in the chart and the word we were looking for.

A different student facilitates each line, and students must correctly place punctuation on the cards and place the words in correct order. Mini-lessons come up around capital letters, consonant blends, diphthongs, word families, and vocabulary. The students continue until they have reconstructed the entire verse correctly.

Vocabulary. I personally don't believe in reviewing vocabulary before students have enjoyed a poem. I do, however, want my students to learn the words that are unfamiliar to them. Generally, our work with vocabulary comes after our initial conversations, but if a student asks what a word means, during an initial conversation, we discuss the meaning then.

After we have dealt with our initial reactions to the poem, we start to pick it apart day by day. During daily warm-ups, when I ask the students to point to a word, I sometimes ask them what the poet meant by that word. I may ask for examples, similes, or definitions. Sometimes I pull the vocabulary words out of the pocket chart, mix them up, and deal them out so that the students must place the right word in the right space in the poem.

Sentence/Grammatical Structure. When teachers isolate words by pulling them from pocket chart and then have the students place them back, the students naturally use syntactical or semantic cues to assist them in their effort. Watching the individual differences between students in determining how to reconstruct the poem or phrase is informative. Each student relies on the skill or cueing system that he or she has most developed. Some students are quite anxious when asked to reconstruct a part of the poem in the pocket chart. They feel that their status among their peers is on the line. They 
don't want to fail. A certain amount of this tension is, I believe, good for motivation, but I am, at the same time, trying to create an atmosphere where no one can fail because it is everyone's responsibility that everyone succeed. Thus, I insist that the students help one another. "We are all students, and we are all teachers." I tell them. I explain that they shouldn't feel ashamed if they don't know something, but they should feel ashamed if they have useful knowledge that they haven't shared with the other members of their community. They shouldn't feel badly if they try, only if they don't.

Once this ethic of collaboration is in place, students are free to be creative in how they solve the problem of learning to read. They begin to develop each of the cueing systems, because I as a teacher have set up their peers as models and teachers. Each of them has a strength or bag of tricks. I try to help them become aware of how it is that they are reading and what they can try when that doesn't work. When they become aware of their strengths, they naturally want to share them. They become the experts, and their status is raised to a new, more exciting level among their peers. I'm like that, too. I want to feel competent, and I want you to feel that way, too.

\section{PERFORMANCE AND EXTENSION (GOING PUBLIC)}

My students have a monthly audience for their work, the people who come to the monthly family meeting. I also try to set up other authentic opportunities for my students to present their hard work. I feel that an incentive to do work that is difficult is knowing that you will have an audience. Thus, we have school performances, we have poetry readings in the school or in bookstores or cafés, we set up displays, we perform for other classes, we invite important people to see our work (actually anyone who walks in the door is fair game). It's fun.

\section{GETTING STARTED WRITING POETRY}

If we make the rich language of poetry a viable part of our students' lives as readers in the classroom, then we will begin to see the students incorporating poetic elements into their own writing. In early literacy programs, teachers use the patterns of predictable text to create class books with innovations on the pattern. Picasso loved Velázquez' painting "Las Meninas." It was reportedly his favorite painting of all time. He spent an entire year painting innovations on this great work. If we want our students to become great writers, we must allow them to innovate on the works of their favorite writers as well.

\section{Poetic Elements (Sound, Rhythm/Line, Imagery, Diction/Tone/Voice)}

Poetic elements are the tools that the poet uses to connect to the poetic moment. In the moment of inspiration, the poet pulls out the tools that fit with his or her experience. For example, this morning I awoke realizing that all migratory birds don't fly south during the winter. The seeds of this realization originally came to me last year when I was in Brazil talking with a colleague about the weather, but the image about the birds came to me in a dream last night. I had been in São Paulo with some Brazilian teachers and asked one of them if it was warmer in Rio de Janeiro. My colleague politely explained that my way of viewing the world now must change because I am south of the equator. The further south you go, the colder it gets. From my dream, which was inspired by this conversation, I realized that if I write a poem about migratory birds from this new point of view, the migration would, at the very least, have a very different rhythm. It would be more like a pulse than north-south, south-north. It would be a pulse from equator to poles and back, as if the planet were exhaling and inhaling birds. It's a strong image that to me makes more sense than the way I was taught that birds fly south. This is a very different image than one I might create based on the idea that birds only fly south in the winter, and I think the tone and the rhythm would be different as well. I now imagine the reunion of birds at the equator as a much bigger and more exciting event!

How a poet interprets an inspiration such as this depends on his or her style and the tools he or she knows how to use. In the hands of each poet, the moment is given a different treatment and is unique. The treatment is based on the poet's craft, skill, and life experience. One thing I know is that poems have existed regardless of culture or geographic location as long as poetic moments have coexisted with the poetic elements of sound, rhythm, imagery, and independent thought and style, or voice, and the poet.

The crafting of a poem is similar to the deconstruction of a poem in Shared Reading in that each poem is different. Each one has a different set of poetic elements to play with, to bring forth, and to study. I refer you to Georgia Heard (1989) and Mary Oliver (1994). By studying what they have to say about how poets use the poetic elements, you can better help your students learn from the poets they study.

\section{Author Studies: Diction/Tone/Voice/Style}

Over time we begin to recognize our favorite poets' style of writing. We try to make explicit what makes a poem special, what sets it apart in diction, tone, voice, and style.

\section{Follow-up}

At the end of the study of a poem, it is helpful to store the poem in a way that allows for easy access by both the students and the teacher. Teacher Rosina Tong laminates posters that she makes of the poems so that they can be hung like shirts in a clothing store. Her students use the laminated poems during DEAR Time. Teacher Dana Romo places completed poems in manila envelopes along with center 


\section{FOCUSO Exceptional children}

activities for independent study. Teacher Margie Pollock makes poster-size versions of favorite (keystone) poems and puts them in a huge box that she makes available to the class. She also has these poems available on sentence strips for independent pocket-chart reading during DEAR Time or in literacy centers.

\section{REFERENCES}

Au, K. H. (1993). Literacy instruction in multicultural settings. Orlando, FL: Harcourt, Brace, Jovanovich.

Barnitz, J. G. (1986). Toward understanding the effects of cross-cultural schemata and discourse structure on second language reading comprehension. Journal of Reading Behavior, 18, 95-113.

Chaudron, C. (1988). Interactive language teaching. Cambridge: Cambridge University Press.

Daniels, H. (1994). Literature Circles. Voice and Choice in the StudentCentered Classroom. Portland, ME: Stenhouse.

Echevarría, J., \& McDonough, R. (1995).. An alternative reading approach: Instructional conversations in a bilingual special education setting. LD Research and Practice, 10, 108-119

Figueroa, R. A. (1992). The failure of the special education reductionist paradigm: The unique case of California's resource specialist program. Unpublished manuscript, California State University Sacramento, The OLE Project.

Figueroa, R. A. \& Ruiz, N. T. (1993). Bilingual pupils and special education: A reconceptualization. In R. C. Eaves \& P. J. McLaughlin (eds.) Recent advances in special education and rehabilitation. New York: Andover Medical, 73-87.

Figueroa, R. A., Ruiz, N. T., \& Rueda, R. (1988). Special education/ demonstration project for Hispanic pupils: The OLE model. Research Proposal University of California at Davis.

Flores, B., Rueda, R., \& Porter, B. (1986). Examining assumptions and instructional practices related to the acquisition of literacy with bilingual special education students. In A. C. Willig \& H. F. Greenburg (Eds.), Bilingualism and learning disabilities (pp. 149-165). New York: American Library.

Goldman, S., \& Rueda, R. (1988). Developing writing skills in bilingual exceptional children. Exceptional Children, 54, 543-551.

Graves, A. W., Valles, E. C., \& Rueda, R. (2000). Variations in writing instruction: A study in four bilingual special education settings. Learning Disabilities Research, 15(1), 1-9.

Greene, J. P. (1998). A meta-analysis of the effectiveness of bilingual education. Manuscript sponsored by the Thomás Rivera Policy Institute, University of Texas at Austin.

Gutiérrez, K., \& Stone, L. D. (1997). A cultural-historical view of learning and learning disabilities: Participating in a community of learners. LD Research and Practice, 12, 123-131.

Heard, G. (1989). For the Good of the Earth and Sun. Teaching Poetry. Portmouth, NH: Heinemann.

Holdaway, D. (1982). Shared book experience: Teaching reading using favorite books. Theory Into Practice, 21(4), p. 293-300.

López-Reyna, N. (1996). The importance of meaningful contests in bilingual special education: Moving to whole language. $L D$ Research and Practice, 11, 120-131.

Moll, L. C. (1992). Vygotsky and Education: Instructional Implications and Applications in Sociohistorical Psychology. Cambridge, N.Y.: Cambridge University Press.

Oliver, M. (1994). A Poetry Handbook. San Diego: Harcourt Brace \& Co.

Ortiz, A., Wilkinson, C. Y., Robertson-Courtney, P., \& Kushner, M. I. (1991). Aim for the BEST: Assessment and intervention model for the bilingual exceptional student. Arlington, VA: Development Associates.

Ramirez, J. D., Pasta, D. J., Yuen, S., Billings, D. K., \& Ramey, D. R. (1991). Final Report: Longitudinal study of structural immersion strategy, early-exit, and late-exit transitional bilingual education programs for language-minority children. Aguirre International Report to the U.S. Department of education, San Mateo, California.

Rueda, R., \& Mehan, H. (1986). Metacognition and passing: Strategic interaction in the lives of students with learning disabilities. Anthropology and Education Quarterly, 17, 145-165.

Ruiz, N. T. (1989). An optimal learning environment for Rosemary. Exceptional Children, 56, 130-144.

Ruiz, N. T. (1995a). The social construction of ability and disability: I. Profile types of Latino children identified as language learning disabled. Journal of Learning Disabilities, 28(8), 476-490.

Ruiz, N. T. (1995b). The social construction of ability and disability: II. Optimal and at-risk lessons in a bilingual special education classroom. Journal of Learning Disabilities, 28(8), 491-502.

Ruiz, N. T., \& Enguídanos, T. (1997). Authenticity and advocacy in assessment: Bilingual students in special education. Primary Voices, 5(3), 35-46.

Ruiz, N. T., \& Figueroa, R. A. (1995). Learning-handicapped classroom with Latino students the optimal learning environment. Education and Urban Society, 27(4), 463-483.

Ruiz, N. T., García, E., \& Figueroa, R. A. (1996). The OLE curriculum guide. Sacramento: California State Bureau of Publications.

Ruiz, N. T. (1999). Effective literacy instruction for Latino students receiving special education services: A review of classroom research. In T. V. Fletcher \& C. S. Bos (eds.), Helping individuals with disabilities and their families: Mexican and U.S. perspectives. Tempe AZ: Bilingual Review/Press, pp. 161-174.

Ruiz, N. T., Vargas, E., \& Beltrán, A. (2001). Literacy research practice and a few questions from bilingual special education. In M. Reyes \& J. Falcón (Eds.), The best for our children: Latino/a voices in literacy. New York: Teachers College Press.

Skrtic, T. (1991). The special education paradox: Equity as the way to excellence. Harvard Educational Review, 61, 148-206.

Snow, C. E., Burns, M. S., \& Griffin, P. (1998). Preventing reading difficulties in young children. Newark, DE: International Reading Association.

SRA/McGraw-Hill. (1996). Open Court school-based results. Unpublished manuscript.

Taylor, D. (1998). Beginning to read and the spin doctors of science. Urbana, IL: National Council of Teachers of English.

TESOL. (1997). ESL standards for Pre-K-12 students. Alexandria, VA: Teachers of English to Speakers of Other Languages.

Tharp, R. (1997). From at-risk to excellence: Research, theory, and principles for practice. Washington, D.C.: Center for Research on Education, Diversity \& Excellence, Center for Applied Linguistics.

Thomas, W. \& Collier, V. (1996). Language minority student achievement and program effectiveness. Unpublished manuscript, George Mason University.

Viera, P. (1986). Remediating reading problems in a Hispanic learning disabled child from a psycholinguistic perspective: A case study. In A. C. Willin \& H. F. Greenburg (Eds.), Bilingualism and learning disabilities (pp. 81-92). New York: American Library.

Willig, A., \& Swedo, J. (April, 1987). Improving teaching strategies for exceptional Hispanic limited English proficient students: An exploratory study of task engagement and teaching strategies. Paper presented at the annual meeting of the American Educational Research Association, Washington, DC. 